\section{Universities and Development}

PNG universities have the potential to offer education, training, and research programs that can support the country's development. A labor force is being trained, especially for basic and secondary education and the country's health needs, as well as future government, civil service, and business leaders. PNG universities also believe they should impart cultural values, attitudes, and ethics that can help to construct a healthy civil society and support good governance and a democratic political system. Another objective is to produce graduates who are keen and able to contribute to their immediate communities and the country.

However, there are many problems facing universities: overcrowding, limited or obsolete libraries, insufficient equipment, outdated curriculum, and underqualified teaching staff, to name just a few. Until quality is improved, graduating students every year from weak programs almost certainly means that, however committed or capable the students, they will be illequipped to satisfy the development needs of the country or to compete internationally.

\section{The Challenge of Ontario's Double Cohort}

\section{Sue Winton and Glen A. Jones}

Sue Winton is a doctoral student in educational administration and Glen A. Jones is associate professor of higher education, at the Ontario Institute for Studies in Education of the University of Toronto. Address: OISE, 252 Bloor St. W., Ontario, Toronto M5S IV6, Canada. E-mail: giones@oise.utoronto.ca.

$\mathrm{T}$ he "double cohort," a perhaps unfamiliar concept outside Ontario, Canada, has been a source of angst for tens of thousands of students, their parents, and the province's postsecondary institutions since 1997. This concept refers to the unique situation of two cohorts graduating from high school at the same time. The challenge of accommodating the double cohort in Ontario's universities and colleges ultimately forced the government to fund a dramatic expansion of postsecondary education.

In 1995, a neoliberal government led by Premier Mike Harris was elected in Ontario under the campaign slogan "Common Sense Revolution." Canada's unique federal structure and decentralized approach to educational policy made it possible for this new provincial government to move quickly to reduce the government's expenditures on education, increase university and college tuition fees, and reduce taxes.
In June 1997, Ontario's Ministry of Education and Training announced that it would eliminate the 13th year of schooling with the introduction of a new four-year secondary school curriculum, effective September 1999. The new curriculum would be phased in one year at a time, but the plan also created a situation in which two cohorts would graduate from high school in 2003: one from the old five-year secondary program and one from the new four-year program. The challenge of accommodating the double cohort in Ontario's universities and colleges prompted new policies and promises from the provincial government.

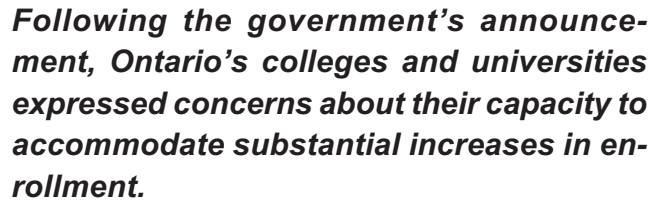

The Need for Expansion

Following the government's announcement, Ontario's colleges and universities expressed concerns about their capacity to accommodate substantial increases in enrollment. In addition to the double cohort, demographic changes associated with the baby boom echo and an overall increase in postsecondary participation rates were also expected to increase demand. The advocacy groups of Ontario's colleges and universities-the Association of Colleges of Applied Arts and Technology of Ontario (ACAATO) and the Council of Ontario Universities (COU) - argued that substantial investment in capital projects, technology, academic infrastructure, and operating grants were crucial.

In the 1999 budget, the government announced the SuperBuild Growth Fund. The new fund would consolidate Ontario's entire infrastructure spending under one program. Over $\$ 740$ million was allocated to postsecondary institutions to build and modernize in anticipation of an expanded student population; $\$ 660$ million of the total was designated for new capital projects, but with private sector contributions this amount was expected to increase significantly. In May 2000, the SuperBuild investment in new capital and facility renewal was increased in hopes of creating 73,000 new student spaces.

While the higher education sector welcomed new capital funding, university and college leaders became increasingly concerned about the absence of increased government commitments in the form of operating grant support for expansion. With the double cohort only three years away, the operating grant announcements for 2000- 
2001 did little but raise the level of anxiety. Only modest funds were directed toward expansion. The government also announced that tuition fee increases for most programs would be capped at 2 percent each year over the next five years.

\section{Funding Expansion}

By late 2000, both the ACAATO and the COU were considering how best to lobby the government for increased operating funds. The COU published a brief arguing that provincial grant increases were needed to hire faculty and meet the demands of increased enrollment. ACAATO established a funding advocacy group that included business, community leaders, students, and alumni.

In May 2001, the government announced a threeyear commitment to increase operating grants in direct proportion to the projected enrollment growth and an additional \$100 million to address current and deferred maintenance expenses. Funding was also committed to improve equipment and facilities for apprenticeship programs in colleges to double the number of new students in skilled trade programs. Plans for the creation of a new public University of Ontario Institute of Technology were also announced.

The double cohort was now receiving considerable attention in the popular media, and the postsecondary sector signaled that the government's announced funding plans were inadequate.

The double cohort was now receiving considerable attention in the popular media, and the postsecondary sector signaled that the government's announced funding plans were inadequate. With only two years before the double cohort graduated from secondary school, leaders within the decentralized higher education policy sector struggled to plan for what might become the largest single-year expansion of postsecondary education in the province's history, without knowing whether a government that was ideologically committed to reducing the size and role of the public sector would provide the necessary funding.

The target of these plans was also moving. By spring 2002, it became apparent that the estimates of the number of new spaces needed to meet the increased demand were too low. Both community college and university enrollments had already exceeded projections. The number of applications for the fall were also higher than anticipated. ACAATO ran ads in newspapers across Ontario that called for an immediate infusion of $\$ 125$ million per year into community colleges to meet the demands of the double cohort.

The double cohort had become a political pressure cooker. Several Ontario university campuses were now among the largest construction sites in the nation. Media reports focused on the concerns of parents, the intense competition among secondary students for high grades, the increased stress within schools associated with a new curriculum, and the uncertainty of how many students would be admitted to postsecondary institutions in 2003. With an unusual level of political capital at their disposal, institutions signaled their willingness to respond as soon as the government committed the necessary funding.

\section{With an unusual level of political capital at their disposal, institutions signaled their willingness to respond as soon as the gov- ernment committed the necessary funding.}

\section{The 2002 Budget}

The 2002 budget committed the government to providing full average cost funding for enrollment growth. It also announced a new round of SuperBuild capital funding, a new equipment and renewal program for the community colleges, and increased funding for apprenticeship programs. By 2003 the government was announcing it had approved capital construction projects that would eventually create a total of 135,000 new student spaces in the system.

When the Ontario university and college application centers released their application statistics for September 2003 admissions, the figures became one of the top provincial news stories of the day. The number of students applying to university directly from high school increased 46.7 percent in 2003, compared with 2002 (an increase of almost 70 percent from the 2001 applicant pool). College applications from students applying directly from high school rose by 9.9 percent, and the number of applications from adult learners increased by 17.5 percent.

With only a few months to go before the arrival of the double cohort, public doubts about the government's ability to deliver on its promise of a space for every qualified and willing student remained. ACAATO continued to voice concerns about the impact of the influx of additional students on the already underfunded system. Finally, in March, the 2003 budget offered some much-needed reassurance. Operating grants were again increased beyond the original commitments, bringing the total to $\$ 443$ million more 
in 2003-2004 than in 2000-2001. Two Quality Assurance Funds were also created.

\section{Maintaining Access}

While the official number of first-year students registered at colleges and universities is not yet available, the COU expected universities to enroll the usual proportion of applicants from Ontario's high schools-a remarkable achievement. In June 2003, close to 72,000 students had accepted positions in the province's universities, and 42,600 confirmed they would attend firstyear classes at one of the community colleges.

Ontario's double cohort is a fascinating case study in the politics of higher education. While governments frequently come under pressure to maintain or increase access, few are forced to address these concerns in the context of a media flurry focusing on the countdown of a very public timeline to address the needs of a specific cohort.

\section{Ross University: Cash Cow or Pig in a Poke?}

\section{Alan L. Contreras}

Alan L. Contreras is the administrator of the Oregon Office of Degree Authorization, 1500 Valley River Drive No. 100, Eugene OR 97401. The views expressed in this article are his own. E-mail: alan.L.contreras@state.or.us.

$\mathrm{D}$ eVry University, a reputable regionally accredited U.S. college that provides a variety of mainly technical programs, announced in spring 2003 that its corporate parent, DeVry Inc., was buying Ross University's medical and veterinary schools in the Caribbean in order to improve and expand DeVry's offerings. It is not unheard of for such international acquisitions to take place, but this one was special: the Ross veterinary school is on the Caribbean island of St. Kitts.

\section{The St. Kitts Situation}

Ross has no authorization to issue degrees anywhere in the United States; its office in New Jersey is expressly limited by that state's laws to noninstructional administrative functions. Therefore, under U.S. law it is a foreign institution, and its degrees must be evaluated as foreign degrees.

Meaningful academic oversight on St. Kitts is doubtful at best. This is the country that once authorized a person in Texas to issue degrees as Eastern Caribbean University. It also hosts Berne University, which recently lost its Title IV approval because of findings by the Gen- eral Accounting Office (the investigatory office of the U.S. Congress) and the U.S. Department of Education that its programs are not equivalent to a U.S. university, its award of credit is inappropriate and excessive, and its finances are questionable.

\section{Multinational Suppliers}

What exactly is the Ross veterinary school? It is not listed by UNESCO (not that this means much for good or ill anymore, since UNESCO has no screening). It does not appear on international lists of universities. The American Association of Collegiate Registrars and Admissions Officers international evaluation office (relied upon by many U.S. colleges for international evaluations) has never seen its degrees. The respected Florida evaluation firm Silny and Associates, which has seen its degrees, considers it only equivalent to an unaccredited U.S. college. It apparently has only a business license from the government of St. Kitts, the college oversight standards of which are, shall we say, opaque.

Has DeVry purchased an overstuffed pig in a foreign poke? Can this reputable U.S. chain school convert this expensive offshore porker that falls well below the normal accreditation radar horizon into a cash cow? Some observers speculate that DeVry assumed that its institutional accreditation from the U.S. North Central Association would automatically extend to cover Ross. Not so, according to the accreditor. Ross is not a unit of DeVry University but a freestanding unit of DeVry, Inc., a parent corporation. Fair enough. Ross must therefore undergo its own evaluation. But by whom and as what?

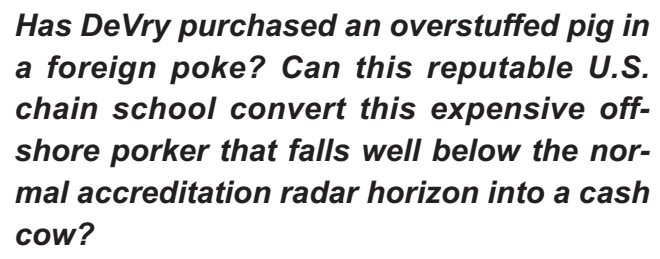
a foreign poke? Can this reputable U.S. chain school convert this expensive offshore porker that falls well below the normal accreditation radar horizon into a cash cow?

\section{Nonexistent Oversight}

DeVry has no apparent plans to make Ross a U.S. accredited school. According to the U.S. Department of Education, DeVry Inc. intends to keep Ross a foreign school for purposes of maintaining eligibility for U.S. financial aid, a much easier approval standard at the federal level in the United States since it requires no proof of academic oversight or quality, just fiscal management and a foreign business license. It appears that neither DeVry nor the Department of Education cares that the Ross vet- 